\title{
Penerapan Model Experiental Learning untuk Meningkatkan Hasil Belajar IPA Fisika Siswa Kelas VII SMP Negeri 5 Palu
}

\author{
Viky Warsito \\ Warsitoviky@rocketmail.com \\ Universitas Tadulako \\ JIn. Soekarno Hatta Km 9 PALU-SULAWESI TENGAH
}

\begin{abstract}
Abstrack - Penelitian ini adalah Penelitian Tindakan Kelas (PTK). Penelitian ini bertujuan untuk meningkatkan hasil belajar fisika siswa kelas VIID SMP Negeri 5 Palu. Masalah yang diteliti adalah rendahnya hasil belajar siswa pada mata pelajaran IPA Fisika. Untuk mengatasi masalah adalah dengan menerapkan model Experiental Learning. Siswa yang terlibat pada penelitian ini berjumlah 16 orang siswa. Data yang diperoleh adalah data kualitatif dan data kuantitatif. Untuk hasil belajar siswa terjadi peningkatan seiring dengan diterapkannya tindakan model Experiental Learning dari siklus I ke siklus II. Hasil analisis tes hasil belajar siswa siklus I yaitu $65 \%$ dengan jumlah siswa yang tuntas sebanyak 7 orang dan yang tidak tuntas sebanyak 9 orang siswa. Karena pada siklus I masih banyak jumlah siswa yang tidak tuntas dibandingkan jumlah siswa yang tuntas, maka penelitian ini dilanjutkan ke siklus II. Pada siklus II hasil analisis tes hasil belajar siswa yaitu $82,08 \%$ dengan jumlah siswa yang tuntas sebanyak 14 orang siswa dan yang tidak tuntas sebanyak 2 orang.

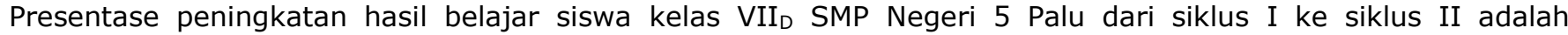
$16,66 \%$. Berdasarkan hasil tersebut dapat disimpulkan bahwa dengan model Experiental Learning dapat

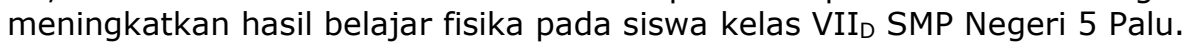

Kata Kunci: Model Experiental Learning, Hasil Belajar Fisika

\section{PENDAHULUAN}

Proses belajar mengajar merupakan proses pendidikan secara keseluruhan, guru sebagai pemegang peran utama. Pendidikan selalu berhubungan dengan upaya pembinaan manusia. Unsur manusia yang paling menentukan keberhasilan pendidikan adalah pelaksana pendidikan yaitu guru, sebab guru secara langsung berupaya mempengaruhi, membina dan mengembangkan kemampuan siswa agar menjadi manusia yang cerdas, terampil, dan bermoral tinggi. Guru dengan sadar mengatur lingkungan pembelajaran agar bergairah bagi siswa dengan seperangkat teori dan pengalamannya. Guru mempersiapkan program pengajaran dengan baik dan sistematik sehingga dalam proses belajar mengajar merupakan suatu kegiatan yang tidak dapat dipisahkan antara siswa yang belajar dan guru yang mengajar. [1]

Hasil observasi sebelumnya di SMP Negeri 5 Palu, diperoleh informasi rendahnya hasil belajar siswa dipengaruhi oleh kurangnya keaktifan siswa dalam belajar fisika, sehingga siswa kurang memahami materi fisika yang diajarkan, karena guru hanya menggunakan satu metode dalam mengajar yaitu ceramah kemudian siswa sebagian besar hanya mendengarkan dan mencatat apa yang diajarkan tanpa terlibat langsung dalam pembelajaran. Untuk mencapai hasil belajar yang baik tentu metode yang digunakan dalam mengajar harus diperbaiki.

Tabel 1 menunjukkan bahwa hasil belajar siswa fisika kelas VII SMP Negeri 5 Palu masih tergolong rendah.

Tabel 1. Nilai Rata-rata Ujian Fisika Semester Ganjil Kelas VII SMP Negeri 5 Palu Tahun Ajaran 2013/2014

\begin{tabular}{|c|c|c|}
\hline No & Kelas & Nilai Rata-rata Fisika \\
\hline 1 & VIIA & 70 \\
\hline 2 & VIIB & 65,8 \\
\hline 3 & VIIC & 60,0 \\
\hline 4 & VIID & 5,50 \\
\hline
\end{tabular}

Hal ini menunjukan akan sulitnya pelajaran fisika yang disebabkan oleh kurangnya antusias siswa untuk belajar fisika sehingga menimbulkan kejenuhan dan kebosanan pada siswa itu sendiri mengakibatkan nilai hasil belajar fisika siswa pada SMP Negeri 5 Palu menjadi rendah. Dengan adanya Kriteria Ketuntasan Minimal (KKM) dijadikan dasar patokan nilai terendah dalam penilaian siswa. Jika siswa mampu mendapatkan nilai diatas KKM maka dianggap siswa tersebut telah tuntas atau menguasai kompetensi yang dipelajari. Sebaliknya jika ditemukan siswa mendapat nilai dibawah KKM berarti perlu adanya perbaikan.

Ada beberapa hal yang menjadi pertimbangan dalam menentukan KKM 
diantaranya tingkat kemampuan rata-rata siswa, kompleksitas, kompetensi dasar, serta kemampuan sumber daya pendukung meliputi warga sekolah, sarana dan prasarana yang mendukung proses pembelajaran.

Melihat data di atas yang diperoleh dari sekolah tersebut, maka peneliti melihat bahwa metode pembelajaran yang digunakan selama ini belum efektif, yang menyebabkan rendahnya hasil belajar fisika siswa khususnya siswa kelas VII SMP Negeri 5 Palu, oleh karena itu, diperlukan adanya penggunaan metode digantikan menjadi model pembelajaran atau suatu bentuk model pembelajaran yang dapat meningkatkan hasil belajar fisika siswa. Permasalahan utama dalam penelitian ini ialah dimana kurangnya minat belajar siswa terhadap pembelajaran fisika yang diterapkan saat ini, sehingga proses pembelajaran di kelas kurang maksimal. Adapun faktor yang mempengaruhi ialah siswa di kelas hanya mencatat dan mendengarkan pembelajaran saja sehingga hal ini perlu dilakukan model pembelajaran yang lebih baik, di mana siswa tidak cenderung bosan di ruang kelas.

Adapun cara yang dilakukan yaitu dengan menerapkan model experiental learning yang merupakan salah satu komponen dalam kegiatan belajar mengajar yang bertujuan untuk meningkatkan hasil belajar fisika di SMP Negeri 5 Palu. Experiental learning adalah suatu proses pembuatan generalisasi-generalisasi dan konklusi-konklusi (kesimpulan- kesimpulan) tentang pengalaman langsung. Model experiental learning merupakan pengalaman langsung dari apa yang sedang di pelajari, membangun keterkaitan sadar untuk belajar dan turut bertanggung jawab didalam pengorganisasian kesimpulan-kesimpulan yang ditarik dari pengalaman-pengalaman sendiri. Dengan model experiental learning ini diterapkan siswa tidak hanya belajar di kelas saja, akan tetapi siswa juga bisa belajar melalui pengalaman-pengalaman sehari-hari yang berkaitan dengan fisika.

Penerapan model experiental learning ini juga dapat melatih siswa untuk dapat berbicara di depan teman-temanya, berdiskusi dan bekerjasama dengan teman-temannya. Hal inilah yang menjadi motivasi penulis untuk meneliti guna melihat sejauh mana model experiental learning dapat meningkatkan hasil belajar fisika siswa kelas VII SMP Negeri 5 Palu.

\section{METODOLOGI}

Penelitian ini merupakan penelitian tindakan kelas yang dilaksanakan pada SMP Negeri 5 Palu khususnya pada kelas VIID. Ruang lingkup dalam penelitian ini adalah hasil belajar siswa materi Suhu Dan Pengukurannya.

Jenis data dalam penelitian ini adalah data kualitatif dan data kuantitatif. Data kualitatif berupa data yang diperoleh dari siswa berupa data hasil observasi, angket respon siswa, serta data observasi kegiatan guru atau peneliti dalam kegiatan belajar mengajar. Data kuantitatif ialah data yang diperoleh setelah proses berlangsung pada setiap siklus berupa hasil tes belajar siswa dalam menyelesaikan materi fisika.

Untuk lebih jelasnya desain penelitian yang digunakan dalam penelitian ini adalah sebagai berikut:

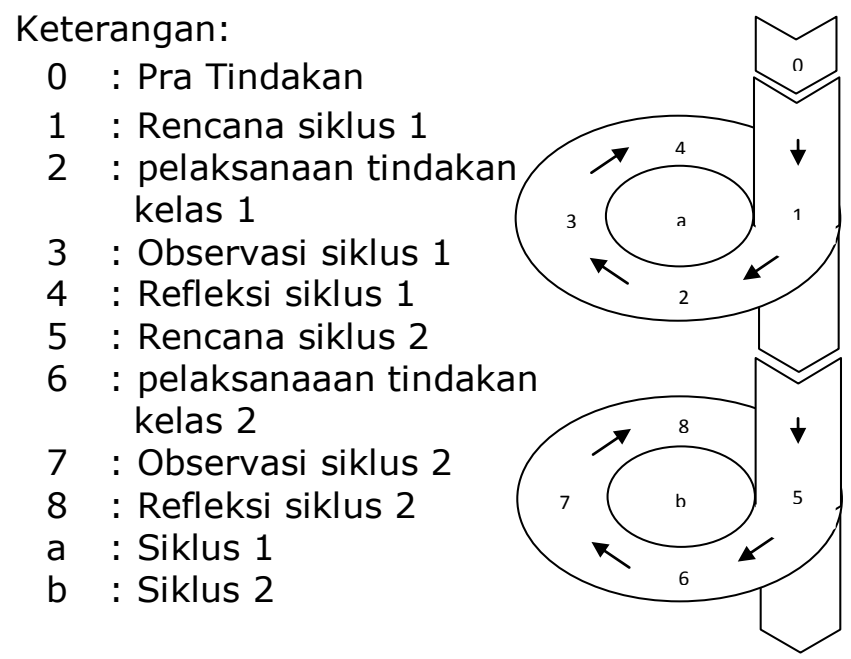

GAMBAR 1 Diagram Alur Desain Penelitian Model Kemmis dan Mc. Taggart Sumber

Dalam penelitian ini ada 3 kriteria hasil belajar siswa

Daya serap secara individu

Analisa data untuk mengetahui daya serap masing-masing siswa digunakan rumus sebagai berikut:

$$
D S I=\frac{\mathrm{X}}{\mathrm{Y}} \times 100 \%
$$

Dimana, $X$ : skor yang diperoleh siswa

$Y$ : skor maksimal soal

DSI : daya serap individu

Ketuntasan Belajar Klasikal

Analisa data untuk mengetahui ketuntasan belajar seluruh siswa yang menjadi sampel dalam penelitin ini digunakan rumus sebagai berikut:

$$
K B K=\frac{\sum N}{\sum S} \times 100 \%
$$

Keterangan:

$\sum \mathrm{N}=$ banyaknya siswa yang tuntas 
$\begin{aligned} \sum \mathrm{S} & =\text { banyaknya siswa seluruhnya } \\ \mathrm{KBK} & =\text { ketuntasan belajar klasikal }\end{aligned}$

Daya Serap klasikal

Analisa data yang digunakan untuk mengetahui daya serap klasikal atau daya serap seluruh sampel penelitian digunakan rumus sebagai berikut:

$$
\begin{aligned}
\text { DSK } & =\frac{\sum \mathrm{P}}{\sum \mathrm{I}} \times 100 \% \\
\text { dengan }: \quad \sum \mathrm{P} & =\text { skor total persentase } \\
\sum \mathrm{I} & =\text { skor ideal seluruh siswa } \\
\text { DSK } & =\text { daya serap klasikal }
\end{aligned}
$$

Pada penelitian ini kriteria hasil aktivitas guru dan siswa kriteria ini terbagi menjadi tiga bagian yaitu aspek afektif, aspek psikomotor dan aspek pelaksanaan guru dan siswa.

Aspek Afektif

Pada aspek afektif, alat ukur yang digunakan berupa lembar penelitian sikap yang terdiri dari 4 aspek penilaian yaitu kehadiran, perhatian mengikuti pelajaran, kerjasama dalam kelompok, partisipasi dalam praktek. Kemudian menghitung persentase rata-rata dengan menggunakan persamaan:

Persentase nilai rata-rata

$$
(N R)=\frac{\text { JumlahSkor }}{\text { SkorMaksimal }} \quad x \quad 100 \%
$$

Data yang terkumpul kemudian dikelompokkan (katergorisasi) dengan skala lima berdasarkan teknik kategorisasi standar. Aspek Psikomotor

Pada aspek psikomotor, alat ukur yang di gunakan berupa lembar penilaian keterampilan yang terdiri dari keterampilan melakukan pengamatan, menyusun alat dan bahan, mengisi LKS, memprediksi data dengan benar, menggunakan alat, menyimpulkan. Kemudian menghitung persentase rata-rata dengan menggunakan persamaan di atas. kemudian di kelompokkan (kategorisasi) dengan skala lima berdasarkan kategori standar.

\section{HASIL DAN PEMBAHASAN}

Berdasarkan penelitian diperoleh hasil penelitian, pada tiap siklusnya seperti pada:

Tabel 2. Aktifitas Siswa

\begin{tabular}{cccl}
\hline Siklus & Pertemuan & $\%$ & Kategori \\
\hline \multirow{2}{*}{ I } & 1 & $62,50 \%$ & Kurang \\
& 2 & $80,00 \%$ & Baik \\
\hline \multirow{2}{*}{ II } & 1 & $87,50 \%$ & Baik \\
& 2 & $97,50 \%$ & Sangat \\
& & & Baik \\
\hline
\end{tabular}

Tabel 3 Aktifitas Guru

\begin{tabular}{|c|c|c|}
\hline Pertemuan & $\%$ & kategori \\
\hline $\begin{array}{c}1 \\
\text { Pfoporsi (咆) }\end{array}$ & $\begin{array}{l}644,45 \% \% \text { i } \\
75,39 \%\end{array}$ & $\begin{array}{l}\text { Cukup } \\
\text { Baik }\end{array}$ \\
\hline $85-1001$ & \multicolumn{2}{|c|}{ 8A, (357argat Bsidk) } \\
\hline $\begin{array}{l}655-84 \\
55-64\end{array}$ & 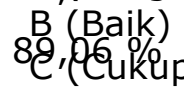 & $\begin{array}{l}\text { Sangat } \\
\text { Baik }\end{array}$ \\
\hline $\begin{array}{l}35-54 \\
0-34\end{array}$ & $\begin{array}{l}\text { D (Kuran } \\
\text { E (Sanga }\end{array}$ & Kurang) \\
\hline
\end{tabular}

\begin{tabular}{cccl}
\hline Siklus & Pertemuan & $\%$ & Kategori \\
\hline \multirow{2}{*}{ I } & 1 & $70,00 \%$ & Cukup \\
& 2 & $80,00 \%$ & Baik \\
\hline \multirow{2}{*}{ II } & 1 & $82,50 \%$ & Baik \\
& 2 & $95,00 \%$ & Sangat \\
& & & Baik \\
\hline
\end{tabular}

Tabel 4 Afektif Siswa

\begin{tabular}{cccl}
\hline \multirow{2}{*}{ Siklus } & Pertemuan & $\%$ & kategori \\
\hline \multirow{2}{*}{ I } & 1 & $61,45 \%$ & Cukup \\
& 2 & $77,08 \%$ & Baik \\
\multirow{2}{*}{ II } & 1 & $84,37 \%$ & Baik \\
& 2 & $91,66 \%$ & Sangat \\
& & & Baik \\
\hline
\end{tabular}

Tabel 5 Psikomotor Siswa

Tabel 6 Hasil Belajar Siswa

\begin{tabular}{clc}
\hline Siklus & \multicolumn{1}{c}{ Aspek Perolehan } & Hasil \\
\hline & Skor tertinggi & 86,67 \\
& Skor terendah & 46,67 \\
& Siswa yang tuntas & 7 \\
I & Siswa yang tidak & 9 \\
& tuntas & $65,42 \%$ \\
& Daya serap klasikal & $43,80 \%$ \\
\hline & Ketuntasan belajar klasikal & 93,33 \\
\hline & Skor tertinggi & 66,67 \\
& Skor terendah & 14 \\
II & Siswa yang tuntas & 2 \\
& Siswa yang tidak tuntas & $82,08 \%$ \\
& Daya serap klasikal & $87,50 \%$ \\
\hline &
\end{tabular}

\section{PEMBAHASAN}

Keaktifan siswa dalam proses pembelajaran di kelas menjadi salah satu faktor yang utama untuk dapat meningkatkan hasil belajar fisika yang baik. Pada model Experiental Learning ini, siswa dituntut untuk dapat bereksperimen, mencoba sendiri, dan menarik kesimpulan 
sendiri, dengan kata lain model Experiental Learningi menuntut keaktifan siswa. Oleh karena itu peneliti menerapkan model Experiental Learning sebagai salah satu strategi belajar yang baik.

Model experiental learning adalah suatu model belajar mengajar yang mengaktifkan siswa untuk membangun pengetahuan dan keterampilan serta nilai-nilai dan sikap melalui pengalaman secara langsung. Melalui prosedur experental learning, siswa dapat dilatih untuk menemukan sendiri, menformulasikan sendiri prinsip-prinsip dan rumus-rumus kemudian menguji keahliannya dalam praktek sehari-hari. Model experiental learning dikembangkan dengan tujuan untuk meningkatkan hasil belajar fisika dan menguji tingkat keaktifan pembelajaran yang dilaksanakan di kelas.

Penerapan model Experiental Learning merupakan model pembelajaran yang baik untuk meningkatkan hasil belajar fisika, seperti telah dilakukan oleh peneliti yang dapat dijelaskan sebagai berikut.

Sebelum masuk ke perencanaan siklus I peneliti memberikan tes pra tindakan kepada siswa yang berjumlah 16 orang. Tujuan dari tes pra tindakan ini adalah untuk mengetahui pengetahuan awal siswa dan pembagian kelompok. Berdasarkan hasil analisis tes hasil belajar pra tindakan hanya mencapai 45,83\% siswa yang tuntas hanya 2 orang sedangkan siswa yang tidak tuntas sebanyak 14 orang. Hal ini disebabkan keaktifan siswa dalam proses pembelajaran masih sangat kurang seperti kurangnya praktek secara langsung di kelas, kurangnya siswa yang bertanya jika ada yang belum di mengerti serta kurangnya keseriusan mereka dalam poses pembelajaran sehingga timbul di pemikiran siswa bahwa belajar fisika sangatlah susah.

Pembentukan kelompok berdasarkan dari hasil tes awal yang telah diberikan. Siswa dibagi menjadi 4 kelompok, masing-masing kelompok beranggotakan 4 orang yang berkemampuan tinggi, sedang dan rendah.

Tahap berikutnya adalah pelaksanaan tindakan yang merupakan prosedur langkahlangkah penelitian. Pelaksanaan tindakan dimulai dari tahap perencanaan, pelaksanaan tindakan, observasi, kemudian refleksi dan yang terakhir adalah evaluasi.

Pada perencanaan siklus I yang perlu dipersiapkan adalah materi pembelajaran, skenario pembelajaran, rencana pelaksanaan pembelajaran, lembar kerja siswa, lembar observasi guru dan siswa, dan yang terakhir adalah tes hasil belajar. Selanjutnya pelaksanaan proses belajar mengajar di kelas untuk siklus I 52,5\%

Hasil analisis observasi keaktifan siswa pada siklus I, dengan 2 pertemuan yaitu pada pertemuan pertama $62,50 \%$ berada dalam kategori kurang sedangkan pada pertemuan kedua $80,00 \%$ berada dalam kategori baik. Sedangkan untuk aktifitas guru pertemuan pertama $70,00 \%$ berada dalam kategori cukup dan pertemuan kedua $80,00 \%$ berada dalam kategori baik.

Presentase aktifitas siswa walaupun tiap pertemuan meningkat namun masih dalam kategori cukup. Rendahnya persentase aktifitas siswa siklus I disebabkan kegiatan siswa yang masih sangat kurang dalam proses pembelajaran siswa masih kurang aktif karena terbiasa dengan pembelajaran sebelumnya dimana siswa hanya sebagai pendengar. Siswa juga masih belum dapat bekerjasama dengan teman sekelompoknya, masih banyak yang bermain dalam kelas. Hal ini tidak sesuai dengan model Experiental Learning karena model Experiental Learning sangat menuntut keaktifan siswa dalam proses pembelajaran di kelas. Karena model Experiental Learning hasilnya pada siklus I belum maksimal maka peneliti melanjutkan ke siklus II.

Berbeda halnya dengan aktifitas guru pada tiap pertemuan, penilaian aktifitas guru terjadi peningkatan pada tiap pertemuan dimana sudah mencapai kategori baik. Hal ini disebabkan karena guru selalu dan terus berusaha memperbaiki cara mengajar agar siswa lebih mengerti dengan pelajaran yang dijelaskan guru dengan menggunakan model pembelajaran Experiental learning.

Setelah selesai 2 pertemuan siklus I, yang terakhir adalah pelaksanaan tes hasil belajar siswa. Hasil analisis tes hasil belajar siswa untuk daya serap klasikal (DSK) adalah 65,42\% dan ketuntasan belajar klasikal (KBK) adalah $43,8 \%$ siswa yang tuntas sebanyak 7 orang dan siswa yang tidak tuntas sebanyak 9 orang. Dari data tes hasil belajar siklus I secara umum dapat dikatakan sudah baik dibandingkan dengan tes awal namun siswayang tidak tuntas masih banyak dan presentase aktivitas siswa juga masih rendah. Hal inilah yang mendasar yang menyebabkan peneliti lanjut ke siklus II.

Hasil Analisis aktivitas siswa pada siklus II yaitu pada pertemuan pertama $87,50 \%$ berada dalam kategori baik dan pada pertemuan kedua $97,50 \%$ berada dalam kategori sangat baik. Peningkatan ini disebabkan karena siswa sudah termotivasi dalam proses pembelajaran, siswa sudah lebih aktif daripada guru. Aktifitas siswa semakin meningkat daripada siklus I. Hal ini 
ISSN 23383240

terlihat pada tes hasil belajar siklus II yang menunjukkan peningkatan yanga sangat baik dimana daya serap klasikal adalah 82,08 \% sedangkan ketuntasan belajar klasikal adalah $87,50 \%$. Siswa yang tuntas sebanyak 14 orang. Sedangkan yang tidak tuntas hanya 2 orang. Siswa yang tidak tuntas ini disebabkan mereka sangat kurang aktif dalam proses pembelajaran.

Sedangakan untuk aktifitas guru diperoleh pada pertemuan pertama yaitu $82,50 \%$ dalam kategori baik dan pada pertemuan kedua yaitu $95,00 \%$ dalam kategori sangat baik. Berdasarkan presentase nilai rata-rata, aktivitas guru dari siklus I ke siklus II menunjukkan kenaikan yang cukup tinggi. Kenaikan presentase aktivitas guru disebabkan karena guru terus berusaha untuk meningkatkan cara mengajar yang baik agar siswa lebih mudah mengerti pelajaran yang diajarkan dengan menggunakan model pembelajaran Experiental learning.

Penilaian sikap dan kelompok dilakukan pada saat tindakan sedang berlangsung di kelas. Siklus I pada awal pertemuan keaktifan siswa masih belum nampak. Hal ini dikarenakan siswa belum terbiasa dengan langkah-langkah model pembelajaran Experiental Learning. Namun pada pertemuan berikutnya siswa sudah mulai aktif dan sudah mulai bertanya jika ada yang belum diketahuinya. Pada Siklus II siswa sudah terlihat terbiasa dengan langkahlangkah model pembelajaran Experiental Learning sehingga hasil belajar siswa lebih baik. Setelah melakukan refleksi terhadap kekurangan yang terjadi pada kegiatan pembelajaran siklus I maka kegiatan pembelajaran yang dilakukan pada siklus II terjadi peningkatan aktifitas belajar, artinya aktifitas siswa lebih banyak daripada guru. Hal ini terlihat dari adanya kesungguhan siswa dalam mengikuti proses pembelajaran. Refleksi siklus II sudah mencapai hasil yang sangat memuaskan sehingga penelitian hanya dilakukan dua siklus.

\section{KESIMPULAN}

Berdasarkan hasil dan analisis data penelitian, maka dapat disimpulkan bahwa penerapan model Experiental Learning dapat meningkatkan hasil belajar fisika siswa SMP Negeri 5 Palu khusunya kelas VIID. Hal ini terlihat pada hasil analisis tes hasil belajar fisiska pada siklus I mencapai $65,42 \%$ dan hasil analisis tes hasil belajar siklus II mencapai $82,08 \%$. Persentase peningkatan hasil belajar siswa adalah 16,66\%. Indikator kualitatif pembelajaran juga sudah memenuhi indikator yang ditetapkan dimana keempat aspek yaitu aktifitas guru, aktifitas siswa, penilaian afektif dan penilaian kelompok sudah berada dalam kategori baik dan sangat baik.

\section{PUSTAKA RUJUKAN}

[1] Arikunto, S. dkk (2008). Penelitian Tindakan Kelas. Jakarta: Bumi Aksara

[2] Munif dan Mosik. (2009). "Penerapan Metode Experiental Learning Pada Pembelajaran IPA Untuk Meningkatkan Hasil Belajar Siswa Sekolah Dasar". Jurnal Pendidikan Fisika Indonesia. 5, 79-82.

[3] Slameto. (2010). Belajar dan Faktor-Faktor Yang Mempengaruhinya. Jakarta: PT Rineka Cipta

[4] warsito, Viky. (2015). Penerapan Model Experiental Learning untuk Meningkatkan Hasil Balajar IPA Fisika Siswa Kelas VII SMP Negeri 5 Palu. Skripsi pada Program Studi Pendidikan Fisika Jurusan Matematika dan Ilmu Pengetahuan Alam Fakultas Keguruan dan Ilmu Pendidikan Universitas Tadulako Palu. Tidak Diterbitkan. 